Discussion Paper No. 10-058

\title{
A Bayesian Approach to Determine the Impact of Institutions on the Unemployment Rate
}

Andreas Sachs

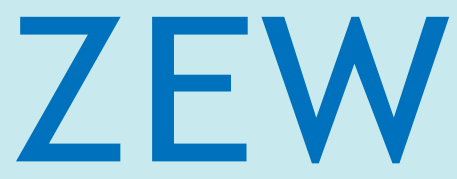

Zentrum für Europäische Wirtschaftsforschung $\mathrm{GmbH}$

Centre for European

Economic Research 
Discussion Paper No. 10-058

\title{
A Bayesian Approach to Determine the Impact of Institutions on the Unemployment Rate
}

\author{
Andreas Sachs
}

Download this ZEW Discussion Paper from our ftp server:

ftp://ftp.zew.de/pub/zew-docs/dp/dp10058.pdf

Die Discussion Papers dienen einer möglichst schnellen Verbreitung von neueren Forschungsarbeiten des ZEW. Die Beiträge liegen in alleiniger Verantwortung der Autoren und stellen nicht notwendigerweise die Meinung des ZEW dar.

Discussion Papers are intended to make results of ZEW research promptly available to other economists in order to encourage discussion and suggestions for revisions. The authors are solely responsible for the contents which do not necessarily represent the opinion of the ZEW. 


\section{Non-technical Summary}

Large differences in the unemployment rates of industrialized countries and the underlying causes of unemployment have been subject of recurring discussion for a long time. Since the early 90's, labor and product market institutions like employment protection legislation, the unemployment benefit system or the labor tax system moved towards the center of attention. However, while theoretical papers provide clear predictions about the impact institutional factors should have on the labor market, empirical contributions disagree as to which factors are of empirical relevance.

One major problem is that institutional concepts used in theoretical work like the bargaining power of workers are unobservable in reality. Although a large number of indicators is available, the low number of observations prevents the inclusion of all of them. Empiricists have therefore to decide which indicators to use in order to capture the effect of a specific institutional concept. However, this pre-selection could give rise to model mis-specification and biased results. This paper offers a solution to this problem by using a bayesian model averaging approach. The major advantage of this method is that a large set of institutional indicators can be tested for significance without running into a degrees-of-freedom problem and without requiring to specify one particular model. Rather, information of a large number of models and, particularly, model uncertainty can be taken into account.

The results show that eight institutional indicators are significant. Each equation claiming to explain unemployment in industrialized countriesshould include these indicators as explanatory variables. More specifically, the payroll and the consumption tax, the first year and the fourth/fifth year benefits, the barriers to entry and the public ownership, the bargaining coordination, and the employment protection legislation are of importance. I check the robustness and reliability of the results by considering heteroskedasticity and endogeneity. Furthermore, the inclusion of additional control variables and the reduction of the sample by excluding countries or periods do not change the results substantially. 


\section{Das Wichtigste in Kürze}

Die Bestimmung der Gründe für erhebliche Differenzen in den Arbeitslosenquoten industrialisierter Länder steht seit langem auf der Agenda von Ökonomen. Seit den frühen 90ern sind Arbeits- und Produktmarktinstitutionen wie der Kündigungsschutz oder die Arbeitslosenunterstützung in den Fokus gerückt. Allerdings ist es bisher empirischen Papieren nicht gelungen, die theoretischen Vorhersagen über den Zusammenhang zwischen Institutionen und Arbeitslosigkeit zu klären.

Ein wesentliches Problem ist, dass theoretische Konzepte wie die Verhandlungsmacht der Arbeitnehmer in der Realität nicht messbar sind. Obwohl eine Reihe an Indikatoren zur Verfügung steht, verhindert die niedrige Beobachtungszahl deren Einbeziehung. Empiriker müssen deshalb Indikatoren auswählen, um das theoretische Konzept abzubilden. Allerdings kann dies zu Modellfehlspezifikationen und fehlerhaften Resultaten führen. Dieses Papier nutzt einen baysianischen Ansatz, um diesem Problem beizukommen. Der wesentliche Vorteil dieser Methode ist, dass so eine größere Anzahl an Indikatoren auf Signifikanz getestet werden kann, ohne dass die Zuverlässigkeit der Ergebnisse leidet.Zudem können Informationen einer erheblichen Anzahl an Modellen in die Evaluation mit einbezogen werden, um so die Modellunsicherheit explizit zu berücksichtigen.

Die Ergebnisse zeigen, dass acht institutionelle Indikatoren signifikant sind. Demnach sollten diese acht Variablen in Betracht gezogen werden, wenn eine Gleichung zur Erklärung der Arbeitslosigkeit geschätzt wird. Im Detail sind die Lohn- und Konsumsteuer, die Lohnersatzraten des ersten und des vierten und fünften Jahres der Arbeitslosigkeit, Markteintrittsbarrieren und Staatseigentum, die Koordination der Lohnverhandlungen sowie der Kündigungsschutz von Bedeutung. Die Zuverlässigkeit der Resultate wurde durch die Berücksichtigung von Heteroskedastizität und Endogenität geprüft. Außerdem ändern sich die Ergebnisse im Wesentlichen nicht, wenn weitere Kontrollvariablen berücksichtigt werden sowie eine Verkleinerung des Samples durch den Ausschluss von Ländern oder Perioden durchgeführt wird. 


\title{
A Bayesian Approach to Determine the Impact of Institutions on the Unemployment Rate*
}

\author{
Andreas Sachs ${ }^{\dagger}$ \\ ZEW Mannheim
}

August 2010

\begin{abstract}
Labor and product market regulations affect the unemployment rate of a country without doubt. Econometricians, however, have yet to establish an unequivocal significance of this impact. Model mis-specification, one of the main underlying problems, is overcome by adopting a Bayesian Model Averaging approach. I apply this method to a panel data set that covers 17 OECD countries for the time period from 1982 to 2005 and for up to 20 potential explanatory variables. 8 institutional indicators are identified as significant determinants of unemployment. Endogeneity due to reverse causality is also considered by applying an instrumental variable estimation approach.
\end{abstract}

JEL classification: C33, E02, E24

Keywords: Unemployment, Institutions, Labor and Product Markets, Model Averaging

*I am grateful to Wolfgang Franz, Jan Hogrefe, Marcus Kappler, Hans-Jörg Schmerer, Andreas Schrimpf, and Werner Smolny for very helpful comments and suggestions. I also thank the participants of the SMYE 2010, the ARGE Workshop 2010, and the ZEW Conference on Recent Developments in Macroeconomics 2010.

${ }^{\dagger}$ Centre for European Economic Research (ZEW), P.O. Box 103443, D-68034 Mannheim, Germany, Phone: +49/621/1235-145, Fax: +49/621/1235-223, E-mail: sachs@zew.de 


\section{Introduction}

Over the past two decades a number of theoretical and empirical studies sought to identify how labor and product market institutions affect the labor market performance of a country. In this context, factors such as the employment protection legislation, unemployment benefits and entry barriers for firms have been considered. Theory predicts a clear impact of institutions on labor market performance. Empirical evidence, however, is yet to confirm the predictions of the theory. The empirical findings fail both to distinguish the crucial from the less important institutions but also to determine whether deregulation lowers or raises unemployment. While the inconclusive results can be partially explained by differences in the time period or the country selection, model mis-specification also seems to be an important source of error.

When it comes to the explanation of unemployment, specifying the model correctly is a challenging task. Researchers benefit from a large pool of potentially significant institutional factors, which also makes the decision on which to include or neglect more difficult. In general, institutional variables can be divided into five groups: tax system, employment protection legislation, workers' bargaining power, product market regulation and unemployment compensation. Each group contains several indicators, measuring different aspects. For instance, bargaining centralization, bargaining coordination, minimum wages, union density and union coverage serve as indicators for the bargaining power of workers.

In principle, one could estimate a single model containing all explanatory variables and let the data sort out the important factors. Availability of macroeconomic data is unfortunately limited to few periods and countries. This prevents me from conducting the described method, since the model's reliability would suffer from the small number of degrees of freedom. Therefore, in order to exploit the complete available set of data, and to separate the important and the less important indicators, a consistent analytical framework is required.

While the outcomes of one single model may not be unreliable, pooling information from a large set of models can improve the validity of the findings. SALA-I-MARTIN ET AL. (2004) introduce such an approach based on a Bayesian-type model averaging, called BACE (Bayesian Averaging of Classical Estimates). The central idea is to estimate a large set of models containing a varying number of explanatory variables taken from the pool of all variables. The quality of a model $j$ serves as a weighting coefficient for the variables $k_{j}$ included in model $j$. Thus, variables which are incorporated in models with better fit receive higher weighting than variables in models that exhibit smaller explana- 
tory power. The weights of a variable over all models are summed up and serve as a measure for evaluating the importance of the factor in explaining the dependent variable. I expect to identify for a given sets of countries and periods indicators for the variables that have contributed robustly to the determination of the unemployment rate. Furthermore, the direction of influence can illuminate the ongoing debate on employment-friendly deregulation reforms and the benefits - if any - of certain institutional rigidities. More specifically, I hope to clarify which institutional changes in product and labor markets facilitate and which hinder the efforts to lower the unemployment rate. Finally, the cross-sectional nature of the data set can shed some light on the question why some countries have lower unemployment rates than others. The last question concerns especially the debate between the "employee-supportive" European system - featuring, e.g., high employment protection and considerable unemployment benefits - and the more "marketfriendly" Anglo-American system.

The paper is organized as follows. In the first part of section 2, I give an overview on the findings of empirical studies dealing with the identification of the direction of influence of institutional variables on the labor market. The second part of this section recapitulates the main theoretical considerations about the impact of institutions on the labor market. Section 3 focuses both on the data as well as on the description of the applied econometric method. Section 4 shows the main empirical results with a corresponding discussion, while section 5 concludes.

\section{Labor and Product Market Institutions}

\subsection{Inconclusive Empirical Results and Specification Problems}

Among studies that have attempted to estimate the effects of institutional factors on unemployment, Nickell et AL. (2005) or Amable et AL. (2007) in a dynamic setting, and Bassanini And Duval (2006) or Baccaro And Rei (2007) for static models are good examples for analyzes in a cross-country context. ${ }^{1}$ However, the results are far from being consistent, showing differences not only in terms of magnitude but also in terms of direction of influence. Howell ET AL. (2007) mention three main causes of the inconclusive results: the selection of the time period, of the institutional indicators, and the specification of the model. While the first point is hard to tackle since data limitations restrict the flexibility of choosing the time period, the latter two aspects can

\footnotetext{
${ }^{1} \mathrm{~A}$ more comprehensive overview on cross-country studies dealing with the identification of the institutional impact can be found in Table 3 in the Appendix.
} 
be reasonably dealt with.

Researchers studying institutions are confronted with the problem of finding indicators which are reasonable proxies for an institution. However, for some institutional categories there are several indicators available which all capture some aspects of an institution. For example, labor taxes consist of taxes payed by the employer, by the employee, and by the consumer. The replacement rate can be split up into the benefit payments for different states of unemployment, say, first year of unemployment or fifth year of unemployment. The bargaining system can be displayed by, for instance, both the union coverage and the bargaining coordination. Furthermore, empirical investigations have generally focused on the impact of labor market institutions on the labor market. The role of product market regulation for the determination of unemployment has been considered by, for instance, Nicoletti And Scarpetta (2005) or Griffith et AL. (2007). However, to my knowledge there are no contributions which particularly deal with the identification of effects on a less aggregate level since in most cases an overall measure of product market regulation is used. ${ }^{2}$ This approach assumes homogeneity of different regulation measures in terms of labor market effects. The selection of indicators is closely related to the question of how to specify the model. A priori neglecting indicators would probably lead to omitted variable bias. Considering all available indicators in one model is often not possible due to the small size of observations in cross-country panels. An incorrectly specified model probably provides misleading results, both concerning significance and direction of influence.

The model averaging framework I apply in this paper enables me to tackle the aforementioned problems. I can include a large set of institutional indicators without being forced to preselect an indicator subset. Furthermore, the uncertainty of not knowing the true econometric model is particularly taken into account. Hence, the main contribution of the paper to the literature is to focus the empirical discussion on factors which indeed are correlated to the unemployment rate. This can help future research to confine attention to relevant variables, leaving out the dispensable ones.

\subsection{Theoretical Mechanisms}

As argued by DAVERI AND TABELlini (2000) labor taxes are assumed to affect the unemployment rate mainly by increasing the cost of labor and, thus, lowering labor demand. Furthermore, the effect of a labor tax increase depends crucially on the degree of the workers' bargaining power. The stronger the workers, the more of the tax increase the

\footnotetext{
${ }^{2}$ One exception is the study of FIORI ET AL. (2007).
} 
firms have to bear. Hence, higher labor taxes only affect labor demand, if the workers' bargaining power is high. An important point is the utilization of the tax income by the government. If part of the taxes serve as funding for, say, qualification measures for unemployed workers to reduce the spell of unemployment, taxes can indirectly help to reduce unemployment.

The wage level is mainly determined by the bargaining system and bargaining power of workers and firms. BLANCHARD AND GiavazzI (2003) show that powerful employees (represented by strong unions) can demand relatively high wages, resulting in lower labor demand and a considerable rise in the number of unemployed. However, CALMFORS (1993) point to the positive labor market effects if unions take into account the negative consequences of their bargaining power. More precisely, if unions keep an eye at the unemployed persons, they will refrain from excessive wage claims for the employed with beneficial effects for the whole economy.

Furthermore, STIGLER (1946) argues that minimum wages reduce labor demand by setting wages above a level which is justified by the workers productivity. Thus, especially low-skilled workers with wage payments below a (hypothetical) minimum wage are blocked out from the labor market. Yet, MANNING (1995) shows in a model of shirking that minimum wages can decrease unemployment by lifting wages to a level at which shirking is less likely due to the increased incentive to work.

Providing employment protection is usually conducted by imposing severance payments on the firm or to exacerbate layoffs by legal regulations. Concerning unemployment, the effect of higher employment protection is assumed to be twofold (see, for instance, LJUNGQVIST 2002). On the one hand, it lowers the flows from employment to unemployment since firms take the additional costs for layoffs in consideration when evaluating the productivity of a worker. On the other hand, labor is allocated less efficiently what comes along with a fall in productivity and, finally, decreased labor demand.

While the employment protection can be seen as an insurance against getting unemployed, the unemployment benefit system affects predominantly those who are already out of work. According to HolmLund (1998), an increase of unemployment benefits on the one hand causes unemployed persons who are eligible to benefit payments to raise their reservation wage. On the other hand, unemployed who are not eligible to benefits will have a higher incentive to accept a job in order to get qualified for the benefit payments in case of future unemployment.

Furthermore, the fear of losing job-specific human capital can convince the workers to attach no importance to high unemployment benefits (see ARULAmpalam 2001). In this case, unemployment benefits will not lower the unemployed workers' incentive to search 
a job.

Additionally, Acemoglu And Shimer (1999, 2000) mention the beneficial influence of unemployment insurance if workers are risk averse. Then, high benefits serve as an insurance against unemployment, and workers are willing to take jobs associated to higher unemployment risk but also to higher wages, higher job quality, and, eventually, increased output and lower unemployment.

The degree of product market regulation affects labor demand through adjusting the competitive environment in a market. Blanchard AND Giavazzi (2003) show that increasing competition in a market means more competition for labor if entry barriers are sufficiently low. Hence, the lower the governmental regulative intervention (e.g. barriers to entry or public ownership) the lower the unemployment rate.

Nevertheless, a certain degree of barriers to entry can also help to increase the firms' productivity in a market, as explained by MELITz (2003). This, in turn, can lead to an increasing demand for labor. Furthermore, a change from public to private ownership boosts the performance of workers and managers since monitoring is much easier to implement (see Schiantarelli (2008) for a discussion).

Besides the traditional institutional variables, some other factors have been brought into the discussion. While data on family policies, migration policies, education and training, active labor market policies, retirement programs as well as the regulation of working hours are only scarcely available, one other variable deserves to be recognized. DromeL ET AL. (2010) recently argued that credit market imperfections can slow down job creation by restricting access to money for firms. The more access to credits is restricted the higher unemployment should be. I consider this variable as a control factor.

\section{Methodology}

\subsection{Data}

The main purpose of the paper is to analyze the impact of labor and product market institutions under model uncertainty. In order to ensure comparability to earlier studies, I rely on established data sources on institutional characteristics. ${ }^{3}$ The existing data have been updated, resulting in a comprehensive and balanced data set from 1982 to 2005. The econometric approach I use requires the application of a panel data without any

\footnotetext{
${ }^{3}$ Oswald (1997) argues that house ownership which is an indicator for the workers' mobility can contribute to the explanation of unemployment. NiCKELL ET AL. (2005) tests this hypothesis and did not find a significant relationship. Additionally, data is only scarcely available and heavily interpolated. Therefore, I do not consider this variable in my estimations.
} 
gaps which is why only 17 OECD countries are included for the investigation. Data on the unemployment rates is taken from the OECD. I use the harmonized unemployment rates which are comparable over countries. ${ }^{4}$ The institutional indicators under inspection are briefly described in the following. Further information on the construction and composition of the data set is given in the Appendix.

- The labor tax system is represented by the payroll tax, the income tax, the consumption tax, and the tax wedge which is the sum of the first three taxes.

- Bargaining coordination and centralization, union density and coverage as well as the minimum wage all cover a part of the bargaining system and the workers' bargaining power.

- The OECD provides an indicator for the strictness of employment protection.

- I construct indicators for the unemployment benefit system according to NiCKELL AND NunziATA (2001). Thus, I have an indicator for the replacement rate for the first year, for the second and third year, and for the fourth and fifth year of unemployment. Additionally, the OECD provides an overall indicator for the replacement rates which is the average of the three aforementioned partial replacement rates, and an indicator for the duration of payment which consists of weighted shares of the first year and the fourth and fifth year benefits. Furthermore, I use a measure for the coverage of the unemployment benefit system, i.e. how many unemployed are entitled to receive transfer payments.

- I use indicators for barriers to entry and for public ownership, as well as an overall indicator for the degree of product market regulation. The overall indicator is the average of different partial indicators of product market regulation. Note, that the barriers to entry and the public ownership indicator are included in the overall indicator. The other parts of the overall indicator cannot be considered since data is missing for some countries or periods.

- According to Dromel Et AL. (2010), I include a measure for credit volume delivered to the private sector over GDP. The higher the value the lower are the constraints to credits.

\footnotetext{
${ }^{4}$ I also run the estimations with data from the Labor Force Surveys collected by the ILO. The results concerning the significance of indicators remain exactly the same.
} 


\subsection{General Empirical Strategy}

The annual unemployment rate is the dependent variable and will be regressed on several institutional factors which explain the long-run evolution of the unemployment rate, and on shocks capturing the short-run fluctuations of the unemployment rate. Furthermore, I use the Within transformation to get rid of time- and country-specific effects. The equation can be expressed as follows:

$$
U R=X_{1} \beta+X_{2} \gamma+\varepsilon
$$

where $U R$ is the unemployment rate $N T \mathrm{x} 1, X_{1}$ is a $N T \mathrm{x} K_{1}$ matrix including all institutional factors which influence the unemployment rate in the long run, and $X_{2}$ is a $N T \mathrm{x} K_{2}$ matrix containing macroeconomic shocks to capture short-run fluctuations. $\beta$ and $\gamma$ are the corresponding coefficient vectors of size $K_{1} \mathrm{x} 1$ and $K_{2} \mathrm{x} 1$, respectively. $\mathrm{N}$ is the number of countries and $\mathrm{T}$ the number of years. ${ }^{5}$

I follow NiCKELL ET AL. (2005) in considering four shock variables. More specifically, I include productivity shocks, labor demand shocks, real import price shocks and the real interest rate. ${ }^{6}$ Unfortunately, it was impossible to construct a money supply shock variable due to data constraints for the time frame required in this paper. However, the results in Nickell et al. indicate at most only slight importance of that shock.

\subsection{Bayesian Model Averaging}

Model mis-specification can lead to severely biased results, mainly due to omitted variable bias, especially if theory does not provide a clear guide on which variables to include. For instance, the workers' bargaining power is an important driver of the unemployment rate, but it is impossible to quantify. Measures like the union coverage or an indicator for the degree of bargaining coordination are often used to proxy the bargaining power. However, there are a lot of potential factors of influence and including all of them is risky due to limitations in terms of degrees of freedom. One possible solution to this problem is to avoid specifying a particular model. Rather, this model uncertainty is particularly taken into account by exploiting information of a large number of models. A particular model

\footnotetext{
${ }^{5}$ It is sometimes argued that institutions do not have the same impact in each country, i.e. the pooling assumption is invalid. The test result for poolability according to BALTAGI (2003) mainly depends on whether I assume an $F$ - or a $\chi^{2}$-distribution. Furthermore, the test results might change when the set of explanatory variables is altered. The gain of lower variance due to pooling comes at the price of a potentially incorrect poolability assumption. This should be kept in mind when interpreting the results.

${ }^{6}$ See the Appendix for further information on the construction.
} 
consists of the fixed regressors plus a random number of varying regressors. In Bayesian terms, the expected coefficient value and the variance of variable can be calculated as follows:

$$
\begin{gathered}
\mathbb{E}(\beta \mid y)=\sum_{j=1}^{2^{K}} P\left(M_{j} \mid y\right) \widehat{\beta}_{j} \\
V A R(\beta \mid y)=\sum_{j=1}^{2^{K}} P\left(M_{j} \mid y\right) \operatorname{Var}\left(\beta \mid y, M_{j}\right)+\sum_{j=1}^{2^{K}} P\left(M_{j} \mid y\right)\left(\widehat{\beta}_{j}-E(\beta \mid y)\right)^{2}
\end{gathered}
$$

where $P\left(M_{j} \mid y\right)$ is the weight of model $j$ in relation to the sum of the weights of all possible models. Thus,

$$
P\left(M_{j} \mid y\right)=\frac{P\left(M_{j}\right) N T^{-k_{j} / 2} S S E_{j}^{-N T / 2}}{\sum_{i=1}^{2^{K}} P\left(M_{i}\right) N T^{-k_{i} / 2} S S E_{i}^{-N T / 2}} .
$$

The term SSE considers the sum of squared errors of a regression to account for the quality of a model, and is corrected for degrees of freedom according to the Schwartz model selection criterion. $N$ is the number of cross-sections, i.e. countries, $T$ is the number of time periods, $K$ is the total number of explanatory variables, and $k$ is the number of explanatory variables in the particular models $i$ and $j . P\left(M_{j}\right)$ is the prior model probability related to model $j$. This probability is calculated as

$$
P\left(M_{j}\right)=\left(\frac{\bar{k}}{K}\right)^{k_{j}}\left(1-\frac{\bar{k}}{K}\right)^{K-k_{j}} .
$$

$P\left(M_{j}\right)$ is a weighting factor to correct for the model size, i.e. for the number of explanatory variables. $\bar{k}$ is the prior model size, $K$ is the total number of available explanatory factors, and $k_{j}$ is the number of explanatory variables included in model $j$. Models with a size close to the prior model size is given a higher weight. In doing so, I correct for the fact, that models with a large number of explanatory variables per se achieve a better fit than models with only few explanatory factors. ${ }^{7}$ It is also possible to calculate the probability that a coefficient has the same sign as its mean conditional on inclusion. This can serve as a check for the reliability of the results delivered by the posterior inclusion probability. A sign certainty probability value close to one means that the coefficient sign of a variable is independent of the model specification.

\footnotetext{
${ }^{7}$ For a detailed description of the method I refer to SALA-I-MARTin ET AL. (2004).
} 
Note, that I only report the estimation coefficients unconditional on inclusion. MAGNUS ET AL. (2010) argue that the conditional estimates overstate the impact of the explanatory factors on the dependent variable. ${ }^{8}$

\section{Estimation Results}

\subsection{Baseline Estimation}

Applying the model averaging approach gives me the posterior inclusion probability and the (weighted) coefficient as well as the (weighted) standard deviation for each factor. Variables with a higher inclusion probability are more likely to be significant explanatory factors of the dependent variable. In other words, the posterior inclusion probability gives a measure of the model fit containing this variable compared to models estimated without this variable. A posterior inclusion probability above the prior inclusion probability complies with a recommendation for including this variable. A value below the prior probability means omission.

I include 3 indicators concerning taxation, 1 measure for employment protection, 5 indicators of the bargaining system, 2 for product market regulation, and 4 measures for the unemployment benefit system. An indicator for credit constraints is included as a control variable. I specify the prior model size to be equal to 6 , i.e. I expect that the model consists of 6 variables. Thus, the prior inclusion probability is $\frac{6}{16}$. The corresponding estimation output can be found in Table 1, where the variables are sorted in descending order regarding their posterior inclusion probabilities in column (1). The weighted coefficients and standard deviations are displayed in columns 2 and 3, while the sign certainty probability can be found in the fourth column. The employment protection legislation, the payroll tax, the consumption tax, and the fourth and fifth year benefits are highly robust with a posterior inclusion probability close to 1 . Similarly, the first year benefits, the public ownership, the barriers to entry and the bargaining coordination also have posterior inclusion probabilities above the prior. If I additionally include a measure for benefit duration, the fourth/fifth year benefits lose significance while the newly introduced duration measure is significant. Hence, the later year benefits can, to some extent, be

\footnotetext{
${ }^{8}$ In their paper, Magnus et al. compare different model averaging techniques and proposes a new method called weighted averaged least squares (WALS). However, to my knowledge, it is questionable whether this method outperforms the BACE approach applied in this paper in terms of reliability of the results. One crucial advantage of the WALS method is its computational simplicity. Since I only rely on up to 18 explanatory variables, the estimations are computationally feasible within the BACE framework which is why I refrain from using the WALS method.
} 
Table 1: Baseline estimation

\begin{tabular}{lcccc}
\hline \hline Prior inclusion prob. & \multicolumn{2}{c}{0.375} & $(\mathrm{k}=6)$ & \\
\hline Variable & $\begin{array}{c}\text { Posterior } \\
\text { inclusion } \\
\text { probability } \\
(1)\end{array}$ & $\begin{array}{c}\text { Posterior } \\
\text { mean }\end{array}$ & $\begin{array}{c}\text { Posterior } \\
\text { standard } \\
\text { deviation } \\
(3)\end{array}$ & $\begin{array}{c}\text { Sign } \\
\text { certainty } \\
\text { probability } \\
(4)\end{array}$ \\
\hline Payroll tax & & & & \\
Employment protection & 0.99 & 0.00207 & 0.00037 & 1.00 \\
Credit access & 0.99 & -0.01816 & 0.00318 & 1.00 \\
Consumption tax & 0.99 & -0.02017 & 0.00384 & 1.00 \\
Fourth/Fifth year benefits & 0.99 & -0.00238 & 0.00053 & 1.00 \\
Public ownership & 0.99 & -0.00061 & 0.00013 & 1.00 \\
Entry barriers & 0.94 & 0.00869 & 0.00218 & 1.00 \\
Bargaining coordination & 0.93 & -0.00563 & 0.00156 & 1.00 \\
First year benefits & 0.89 & -0.00417 & 0.00121 & 0.99 \\
& 0.82 & 0.00034 & 0.00011 & 0.99 \\
Union coverage & & & & \\
Income tax & & & & \\
Bargaining centralization & 0.26 & 0.00039 & 0.00019 & 0.97 \\
Unemployment benefits coverage & 0.07 & 0.00130 & 0.00064 & 0.96 \\
Minimum wage & 0.06 & -0.00549 & 0.00436 & 0.94 \\
Second/Third year benefits & 0.05 & -0.00006 & 0.00017 & 0.83 \\
Union density & 0.04 & -0.00020 & 0.00031 & 0.72 \\
\hline
\end{tabular}

The dependent variable is the unemployment rate. Overall, $65536\left(2^{16}\right)$ estimations have been performed. The shock variables (labor demand shock, productivity shock, real import price shock and the interest rate) are included in each regression. Fixed country- and time-specific effects are swept by using the Within transformation (see Baltagi 2003).

seen as a proxy for the benefit duration. Whether the later year benefits or the benefit duration indicator is included does not affect the remaining indicators.

Turning to the direction of influence, one can see that the majority of robust variables has a negative impact on unemployment. An increase in the employment protection legislation, the bargaining coordination, the access to credits, the barriers to entry, the consumption tax as well as in the fourth and fifth year benefits tends to lower the unemployment rate. In contrast, the payroll tax, the public ownership, and the first year benefits are positively related to the unemployment rate. Note that the sign certainty probability measures conform to the posterior inclusion probabilities. Significant variables concerning the latter 
measure have sign certainty probabilities close to $1 .^{9}$

\subsection{Alternative Prior Model Sizes and Other Modifications}

The prior model size is a factor which serves as a sensitivity check. Such a check has to focus on the comparison of results produced assuming distinct prior model sizes. In the baseline specification I have relied on a prior model size of 6 . Now I perform the same estimations for prior model sizes of 2, 4, 8 and 10. Running this kind of sensitivity check for the baseline estimation shows that most of the outcomes are insensitive to the variation of the prior model size. I have considered 16 institutional indicators in the analysis,

Table 2: Different inclusion probabilities

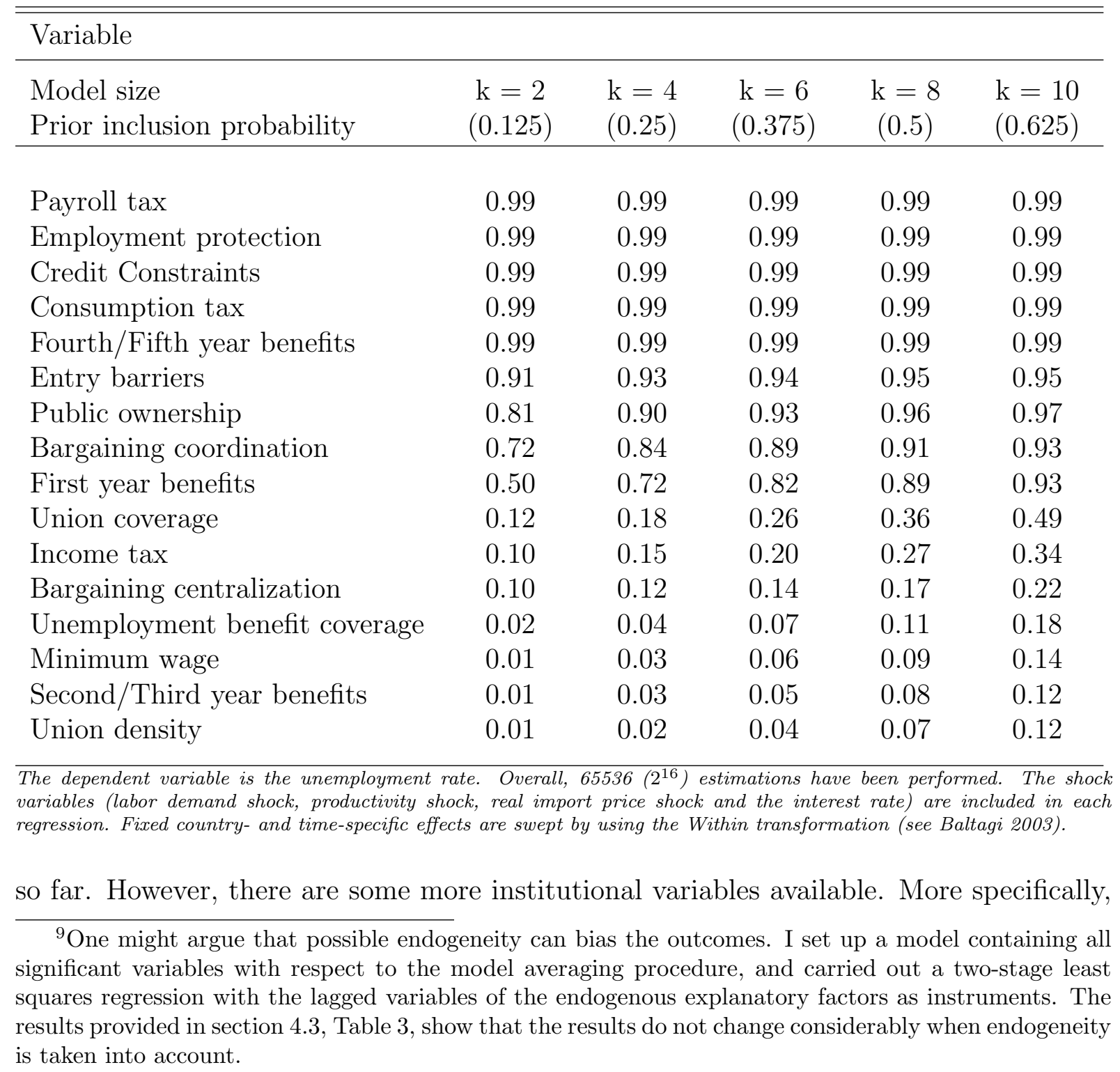


I have indicators for the overall unemployment benefits, the tax wedge, the benefit duration, and the overall product market regulation. I have neglected these indicators in order to avoid multicollinearity in the estimation. This might occur since the mentioned indicators are products of some other indicators which I have already considered in the estimations. For example, the tax wedge is just the sum of the payroll, the income, and the consumption tax. Including them might vary the findings concerning the indicators of the same category, while the remaining indicators should show similar results.

Indeed, the inclusion of the four additional variables has only a small impact. Merely the tax wedge shows robustness with a positive coefficient. The overall benefits, the overall product market regulation as well as the benefit duration are not significant. Note that when including the benefit duration the fourth and fifth year benefits inclusion probability drops independently of the prior model size. Apart from that, the same indicators are robust, only the inclusion probabilities for some variables fall such that only 4 factors have an inclusion probability close to 1 . This can be explained by the larger number of models to be estimated. For the model with 16 explanatory variables, I estimate $2^{16}$, i.e. 65536 different models. The setup with 20 variables and 1048576 models lowers the relative model quality of each model compared to the remaining models and, consequently, the posterior inclusion probabilities.

Furthermore, one might argue that the shocks which are included in each single model have an impact which lasts more than one year. Hence, I extended the set of fixed regressors by taking into account the lagged values of the shock variables. This reduces the estimation period to 1983 to 2005. Again, I can only report slight changes in the findings. The inclusion probabilities of the bargaining coordination and the first year benefits drop considerably but are still clearly above the prior.

Additionally, according to BACCARO AND REI (2007) I included the change in the inflation rate and the lagged labor productivity growth as macroeconomic controls. The results hold independent of the inclusion of both variables. Only the bargaining coordination posterior inclusion probability drops from 0.88 to $0.63 .{ }^{10}$

\subsection{Single Model Estimation}

The model averaging approach serves to identify significant variables. However, it is not appropriate to allow for several extensions of the econometric model. Hence, I set up a model consisting of those institutional variables which have been identified as signif-

\footnotetext{
${ }^{10}$ The construction of the TFP shock might be exposed to measurement error. Hence, I use a different factor for this shock, namely the TFP growth rate from the Total Economy Database provided by the Conference Board. Including this alternative variable has no impact on the results.
} 
icant in the model averaging framework, additional to the usual shock variables. Once a reasonable number of institutional indicator is selected, the single model approach is more flexible. In this single model, I can allow for cross-section heteroscedasticity and endogeneity. The endogeneity problem is tackled by applying instrumental variable estimation. I use the lagged values of the endogenous variables as instruments. However, I first have to check whether the lagged values are adequate instruments for the endogenous factors. I assume that all 8 institutional variables are endogenous and use the two-stage least squares estimation as my instrumental variable approach. The F-statistic of the first stage regression of the endogenous variables on the exogenous ones to test for joint significance of the instruments are displayed in table 3.

Table 3: Test statistics of first stage regressions

\begin{tabular}{lcc}
\hline \hline Endogenous Variables & F-statistic & R squared \\
\hline Payroll tax & 124.372 & 0.811 \\
Consumption tax & 104.529 & 0.783 \\
Bargaining coordination & 143.808 & 0.832 \\
Employment protection & 17.024 & 0.370 \\
Public ownership & 118.546 & 0.803 \\
Entry barriers & 207.067 & 0.877 \\
First year benefits & 323.015 & 0.918 \\
Fourth/Fifth year benefits & 81.374 & 0.737 \\
\hline Results of the first stage regressions according to the two-stage least squares procedure of table 4, columns (3) and (4).
\end{tabular}

Obviously, the F-statistics of the first stage regressions are above a value of 10 what is usually seen as the threshold level for weak instruments (see STOCK AND STAIGER 1997). According to this, by using the lagged values of the endogenous variables as instruments I can take the endogeneity problem into account. Table 4 presents the results of this single model estimation.

Specification (2) is estimated with the heteroskedasticity-consistent White estimator. Specification (3) uses two-stage least squares with the lagged values of the endogenous variables as instruments. Specification (4) additionally includes the output gap as a control variable. This has been done to test whether the shock variables are indeed able to completely capture business cycle dynamics of the unemployment rate. Although the output gap is highly significant, the institutional results do not change substantially. 
Table 4: Single model estimation

\begin{tabular}{|c|c|c|c|c|}
\hline \multirow[t]{2}{*}{ Independent variable: } & \multicolumn{4}{|c|}{ Unemployment rate } \\
\hline & (1) & $(2)$ & $(3)$ & (4) \\
\hline Payroll tax & $\begin{array}{c}0.200^{* *} \\
(0.035)\end{array}$ & $\begin{array}{l}0.200^{* *} \\
(0.035)\end{array}$ & $\begin{array}{c}0.267^{* *} \\
(0.042)\end{array}$ & $\begin{array}{c}0.177^{* *} \\
(0.040)\end{array}$ \\
\hline Consumption tax & $\begin{array}{r}-0.238^{* *} \\
(0.045)\end{array}$ & $\begin{array}{r}-0.238^{* *} \\
(0.044)\end{array}$ & $\begin{array}{c}-0.250^{* *} \\
(0.059)\end{array}$ & $\begin{array}{r}-0.148^{* *} \\
(0.056)\end{array}$ \\
\hline Bargaining coordination & $\begin{array}{r}-0.407^{* *} \\
(0.271)\end{array}$ & $\begin{array}{r}-0.407^{* *} \\
(0.105)\end{array}$ & $\begin{array}{c}-0.526^{*} \\
(0.217)\end{array}$ & $\begin{array}{c}-0.488^{*} \\
(0.195)\end{array}$ \\
\hline Employment protection & $\begin{array}{r}-1.832^{* *} \\
(0.111)\end{array}$ & $\begin{array}{r}-1.831^{* *} \\
(0.264)\end{array}$ & $\begin{array}{r}-1.764^{* *} \\
(0.312)\end{array}$ & $\begin{array}{r}-1.269^{* *} \\
(0.290)\end{array}$ \\
\hline Public ownership & $\begin{array}{c}0.921^{* *} \\
(0.148)\end{array}$ & $\begin{array}{c}0.921^{* *} \\
(0.168)\end{array}$ & $\begin{array}{l}1.265^{* *} \\
(0.208)\end{array}$ & $\begin{array}{l}1.061^{* *} \\
(0.188)\end{array}$ \\
\hline Entry barriers & $\begin{array}{c}-0.592^{* *} \\
(0.175)\end{array}$ & $\begin{array}{c}-0.592^{* *} \\
(0.145)\end{array}$ & $\begin{array}{r}-0.826^{* *} \\
(0.177)\end{array}$ & $\begin{array}{r}-0.693^{* *} \\
(0.160)\end{array}$ \\
\hline First year benefits & $\begin{array}{c}0.032^{* *} \\
(0.010)\end{array}$ & $\begin{array}{l}0.032^{* *} \\
(0.011)\end{array}$ & $\begin{array}{l}0.029^{*} \\
(0.011)\end{array}$ & $\begin{array}{c}0.029^{* *} \\
(0.010)\end{array}$ \\
\hline Fourth/Fifth year benefits & $\begin{array}{r}-0.059^{* *} \\
(0.127)\end{array}$ & $\begin{array}{r}-0.059^{* *} \\
(0.012)\end{array}$ & $\begin{array}{r}-0.058^{* *} \\
(0.015)\end{array}$ & $\begin{array}{r}-0.052^{* *} \\
(0.014)\end{array}$ \\
\hline Credit constraints & $\begin{array}{r}-1.976^{* *} \\
(0.371)\end{array}$ & $\begin{array}{c}-1.976^{*} \\
(0.350)\end{array}$ & $\begin{array}{r}-1.603^{* *} \\
(0.386)\end{array}$ & $\begin{array}{r}-1.877^{* *} \\
(0.349)\end{array}$ \\
\hline Output gap & - & - & $\begin{array}{l}- \\
-\end{array}$ & $\begin{array}{c}-0.323^{* *} \\
(0.039)\end{array}$ \\
\hline Instruments & no & no & yes & yes \\
\hline Heteroscedasticity & no & yes & no & no \\
\hline Shocks & yes & yes & yes & yes \\
\hline Countries & 17 & 17 & 17 & 17 \\
\hline Time & $82-05$ & $82-05$ & $83-05$ & $83-05$ \\
\hline R squared & 0.484 & 0.484 & 0.473 & 0.576 \\
\hline
\end{tabular}

Institutional variables which have been identified as significant within the model averaging framework are included as explanatory factors. Fixed country- and time-specific effects are swept by using the Within transformation (see Baltagi 2003). Institutions lagged by one year are used as instruments for the contemporaneous institutions. All institutional variables are assumed to be endogenous in specification (3) and (4). The shock variables are labor demand shock, real import price shock, TFP shock and the real interest rate. One asterisk marks significance at the $5 \%$ level, two asterisks at the $1 \%$ level, standard deviations appear in parenthesis. 
As a further robustness check, I successively exclude 5 year periods from the sample, starting with the period from 1982 to 1986, then 1987 to 1991, and so on. This sample reduction has only an impact on the first year benefits which become insignificant for the panel from 1987 to 2005.

Another check is to leave out each country at a time in specification (2). While the results for the payroll and the consumption tax, the bargaining coordination, the public ownership, the barriers to entry, and the credit constraints still hold, the first year benefits turn out to be insignificant if I exclude Canada. The effect on the fourth and fifth year benefits is even more severe. When excluding one of the following countries, Denmark, the Netherlands, Norway, Spain, or Switzerland, the fourth and fifth year benefits are insignificant. I interpret this finding as a sign for the heterogeneous impact of the unemployment benefit system in different countries. One reason could be the dependence on other institutional or macroeconomic conditions.

\subsection{Discussion}

I expect the tax system to be positively correlated with the unemployment rate. In fact, I estimate a positive coefficient for the payroll tax rate and for the tax wedge. The income tax is not significant. Furthermore, the consumption tax is negatively related to the unemployment rate, i.e. the higher the consumption tax, the lower the unemployment rate. Studies like Planas ET AL. (2007) or DAVERI AND TABellini (2000) find a negative labor market impact of labor taxes, but they use a measure which only takes labor taxes and social security contributions into account. NiCKELL ET AL. (2005) for a dynamic specification or BACCARO AND REI (2007) for a static model report insignificant tax coefficients. However, both studies include the consumption tax in the tax measure calculations. On the micro-level, Bennmarker ET AL. (2009) report positive employment effects caused by reduced payroll taxes. Assuming a positive impact of higher consumption taxes on the labor market, the insignificant result could be the consequence of two effects in opposite directions, a negative payroll and a positive consumption tax effect. The insignificant impact of income taxation seems to support the assumption that the workers' bargaining power is not strong enough to shift the burden of an income tax increase on the firms. The positive consumption tax coefficient is, at least at first glance, difficult to explain since it is hard to imagine why higher taxes should lead to less unemployment. Possibly, the consumption tax rate has not direct effect on the unemployment rate, but works indirectly on the labor market through a variable which is omitted in the estimation. One candidate is the spending on active labor market policies, financed 
by the governmental tax revenues. These policies are usually assumed to support the unemployed to find a job, be it by training, further education or additional qualification. Indeed, the consumption tax and the almp spending are highly positively correlated. In contrast, there is no positive relationship between almp and the remaining tax measures. ${ }^{11}$ Hence, I assume that including an adequate and comprehensive indicator for governmental training and qualification expenditures would at least dampen the positive consumption tax effect. ${ }^{12}$

While five indicators for different aspects of the bargaining system and power have been analyzed, only one of them turns out to be robustly related to the unemployment rate. More specifically, the higher the bargaining coordination the better the labor market performance. The bargaining centralization, the union density, as well as the union coverage do not seem to be of importance. This is in line with the results summarized in AIDT And Tzannatos (2008). Nickell et AL. (2005) also find a negative relationship between bargaining coordination and unemployment. However, they also report significant union density coefficients, what might be caused by the use of a less exact indicator. The high correlation between the indicators for bargaining coordination and bargaining centralization of 0.62 indicates, that the impact of the centralization measure is at least partially captured by the coordination indicator. Furthermore, similar to most empirical studies, I do not find a robust empirical evidence for a humped-shaped relationship between bargaining coordination or centralization and the unemployment rate, an idea originally proposed by CALmFors AND Driffill (1988). Depending on the number of included variables, I get inclusion probabilities slightly above or considerably below the prior inclusion probabilities for bargaining coordination.

Similarly, minimum wages do not contribute to the evolution of the unemployment rate. The positive and negative effects of minimum wages seem to cancel each other out. The result confirms the findings of ADDISON ET AL. (2009) (also see the references therein) on the micro-level, or BASSANINI AND DUVAL (2006) in a cross-country framework. Both studies report no significant impact of minimum wages on labor market performance. Theoretically, the influence of high employment protection is ambiguous since both the flows into and the flows out of employment are lowered, and it is unclear, which one

\footnotetext{
${ }^{11}$ I did not include an almp measure in the estimations since it is not comprehensively available. However, I use a measure for governmental public spending in the estimations. The results concerning consumption taxes remain unchanged, probably due to the fact that public spending does not reliably capture the spending in training measures.

${ }^{12}$ It is sometimes argued that consumption taxes are less distortionary and performance-increasing, compared to income or payroll taxes. Tax systems which are mainly based on consumption taxes should therefore be less distortionary, with positive effects on the macroeconomic performance. However, the data does not reveal any systematic relationship between the different tax measures and the unemployment rate. Countries with higher consumption taxes do not generally have lower income and payroll taxes.
} 
prevails. The empirical literature does not agree on the labor market effects of employment protection legislation. While studies like Elmeskov ET AL. (1998) find an unemployment-enhancing impact, BAKER ET AL. (2005) report the contrary. Additionally, BACCARO AND REI (2007) do not find any significant effect. The indicator for the degree of employment protection is highly robust. My findings indicate that a stronger protection leads to lower unemployment. However, the indicator I use shows only few time-variation. For some countries there is even no change over the whole period. While the results indicate the relevance of employment protection at least in terms of the crosscountry dimension, the indicator might not to be able to fully capture all dimensions of firing restrictions inside a country. This abates the reliability of the results.

The empirical literature on the unemployment benefit system is ambiguous. The microevidence suggests that rising unemployment benefits has probably negative but rather small effects on the unemployment rate. LALIVE (2007) and VAN OURS AND VodopiveC (2008) find at most a small impact on the unemployment rate of a cut in the duration of benefit payments. Furthermore, RøED AND ZAHNG (2003) state that an increase in the unemployment compensation in Norway reduces the escape rate from unemployment. NiCKELl ET AL. (2005) or the OECD (2006) find a clearly negative effect of benefit levels and, to a smaller extent, of benefit duration on the labor market, while BAKER ET AL. (2005) report the contrary. Apart from the fact that unemployment benefit payments are fairly heterogeneous across countries and time I find that high benefits paid during the first year of unemployment increase the unemployment rate. This is largely in line with the impact reported in the literature. More interestingly, high benefits for long-term unemployed seem to lower the unemployment rate. This confirms the findings of TATsiramos (2009) who mentions the improved matching quality and the positive impact on the next post-unemployment job.

The findings concerning the impact on unemployment of product market regulation point to a positive effect of public ownership and a negative effect of barriers to entry. GRIFFITH ET AL. (2007) estimated that an increase in competition lowers employment, but used a less comprehensive data set compared to the one I constructed. FIORI ET AL. (2007), using the same indicators as I did, report insignificant public ownership and negative entry barriers coefficients. However, they focus mainly on product and labor market interactions and did not pay much attention to the single product market measures. Another study using the same data is the one by Nicoletti AND SCARPetTA (2005). They include an overall indicator for product market regulation, the overall indicator less public ownership, and the public ownership. All three indicators are negatively related to the labor market performance. Furthermore, Bertrand AND Kramarz (2002) show 
for the French retail industry that entry barriers lower employment growth. Hence, my results with respect to the overall indicator and public ownership confirm previous findings, while the finding concerning the barriers to entry tell a different story compared to the existing literature. ${ }^{13}$

\section{Conclusions}

The aim of this paper is to assess which institutional indicators are related to the equilibrium unemployment rate for a panel of 17 countries over the last two decades. The results show that a number of institutional indicators are robustly linked to the evolution of the unemployment rate. More specifically, robust factors are the employment protection legislation, the public ownership and the barriers to entry, the payroll tax and the consumption tax rate, the bargaining coordination, as well as the unemployment benefits for the first year, and the fourth and fifth year of unemployment. Except of the unemployment benefits for which the impact on the unemployment rates does not seem to be homogeneous across countries, the results are insensitive to several changes of the estimation setup.

I find that institutional categories cannot be characterized by one specific indicator, since for some categories countervailing effects are at work. For example, while the first year unemployment benefits lower are negatively related to the unemployment rate, high benefits for long-term unemployed are linked to low unemployment rates. Overall, 5 indicators positively affect the labor market performance. An increase in the employment protection, entry barriers, bargaining coordination, consumption tax, and the benefits for long-term unemployed seem to reduce the unemployment rate. Raising the first year benefits, the payroll tax as well as the public ownership negatively influences the unemployment rate. This emphasizes the importance of considering the right indicators when dealing with the empirical assessment of institutions.

One crucial problem of empirical cross-country studies so far has been the difficulty of specifying the empirical model correctly, mainly due to the large number of possibly important indicators. My findings can pave the way to a more sophisticated empirical assessment of the impact of institutions on the labor market by providing a traceable and reasonable number of institutional indicators. Problems like the design and implementation of institutional reforms, the identification of institutional interactions or even of

\footnotetext{
${ }^{13}$ Note that Fiori et AL. (2007) as well as Bertrand and Kramarz (2002) use employment as the dependent variable. Hence, the impact of regulation on employment and unemployment might not be directly comparable.
} 
regulatory frameworks can be tackled with my results in mind. 


\section{Appendix}

\subsection{Literature Overview on Institutions and Unemployment}

Table 3 summarizes most of the cross-country studies prepared over the last 15 years, dealing with the identification of how institutions affect the labor market. I prepared this table in the style of HowELL ET AL. (2007). A positive impact through an increase in an institution on the labor market (for instance, a lower unemployment rate) is indicated by pos, the contrary is displayed by neg, and an insignificant effect is insig. Since most of the studies estimate several specifications, there might be a positive, negative and insignificant effect for one institutional indicator in one study.

Table 5: Summary for the effects on unemployment of changes in institutions

\begin{tabular}{|c|c|c|c|c|c|c|c|c|}
\hline Study & EPL & RR Level & RR Dur & UD & $\mathrm{UC}$ & $\mathrm{BCO}$ & $\mathrm{BCE}$ & Taxes \\
\hline Scarpetta 1996 & neg/insig & neg & - & neg & - & pos & - & insig \\
\hline Nickell 1997 & insig & neg & neg & neg & neg & pos & - & neg \\
\hline $\begin{array}{l}\text { Elmeskov et al. } \\
1998\end{array}$ & neg/insig & neg & - & pos/insig & - & pos & insig & neg/insig \\
\hline $\begin{array}{l}\text { Blanchard/Wolfers } \\
2000\end{array}$ & neg/insig & neg/insig & neg & neg/insig & insig & neg & - & neg/insig \\
\hline IMF 2003 & neg & pos/insig/neg & - & neg & - & pos & - & neg \\
\hline $\begin{array}{l}\text { Belot/van Ours } \\
2004\end{array}$ & pos/insig & pos/insig/neg & - & neg/insig & - & - & pos/insig & neg/insig \\
\hline Baker et al. 2005 & pos/insig & pos/insig & pos/insig & insig & insig & pos/insig & neg/insig & - \\
\hline Nickell et al. 2005 & insig & neg & neg/insig & neg/insig & - & pos & 一 & neg/insis \\
\hline $\begin{array}{l}\text { Nicoletti/Scarpetta } \\
2005\end{array}$ & neg/insig & neg/insig & - & neg & - & pos/insig & - & neg \\
\hline $\begin{array}{l}\text { Bassanini/Duval } \\
2006\end{array}$ & pos/insig & neg/insig & neg & pos/insig & - & pos/insig & - & neg \\
\hline OECD 2006 & insig & neg & neg & neg/insig & - & pos & - & neg \\
\hline Baccaro/Rei 2007 & insig & insig & - & neg/insig & - & neg/insig & 一 & pos/insig \\
\hline Dority/Fuess 2007 & - & neg/insig & insig & - & pos/insig & pos/insig & - & - \\
\hline Amable et al. 2007 & pos/insig & neg/insig & - & neg/insig & - & pos/insig & - & insig \\
\hline
\end{tabular}




\subsection{Data Sources and Construction}

All variables are on an annual basis and have been gathered for the period from 1982 to 2005. Note, that the data set is balanced. The countries included in the analysis are Australia, Austria, Belgium, Canada, Denmark Finland, France, Germany, Italy, Japan, the Netherlands, Norway, Spain, Sweden, Switzerland, the United Kingdom, and the United States. For countries like Ireland, Portugal, New Zealand or Korea some data is missing which is why I had to exclude them.

\subsubsection{Unemployment Rate}

The dependent variable in the empirical analysis is the harmonized unemployment rate taken from the OECD key short-term economic indicators database. Some data is missing for earlier periods of some countries. To ensure consistent time series, I calculate the growth rates of the unemployment rate as a percentage of civilian labor force (which is not harmonized) and extend the harmonized unemployment rates by concatenating the change of the country-specific unemployment rate. Of course, this could give rise to criticism since it is doubtful whether the unemployment rates for early periods are comparable or not. However, only Austria from 1982 to 1992, Germany from 1982 to 1990 and Switzerland from 1982 to 1991 are affected by this adjustment. Therefore, I prefer to have a larger data set at the expense of a probably small bias.

To check for robustness, I also use the unemployment rates based on labor force surveys provided by the ILO. When data is missing, observations have been constructed based on the growth rates of the employment office records unemployment rates using the same approach as for the OECD series.

\subsubsection{Institutions}

I have four indicators for the tax system, the payroll tax, the income tax, the consumption tax rate, and the sum of these three factors, which is the tax wedge. The taxes have been constructed according to the definition given in NickELL AND Nunziata (2001). The payroll tax $t 1$ is calculated as

$$
t 1=\frac{e s s}{i e-e s s}
$$


with ess equal to the employer's social security contributions and ie equal to the compensation of employees. The income tax $t 2$ is

$$
t 2=\frac{i t}{h c r}
$$

where it is the direct tax spending and hor the household current receipt. Finally, the consumption tax $t 3$ is the result of

$$
t 3=\frac{t l s}{f c e}
$$

with $t$ ls equal to taxes less subsidies on products and imports and $f c e$ equal to the final consumption expenditure of households. The tax wedge tw is calculated as $t w=$ $t 1+t 2+t 3$.

Note that I did not just update the Nickell and Nunziata data but recalculated the whole series. Some considerable changes compared to the Nickell and Nunziata data occurred probably due to data updates made by the OECD.

Overall, four indicators for the bargaining system and power are available. The union density, union coverage, minimum wages, bargaining coordination and bargaining centralization all have been taken from the Visser database (see VIssER 2009). The bargaining coordination is an index ranging from 1 to 5 with 1 indicating fragmented bargaining at the company level, and 5 indicating economy-wide bargaining. The bargaining centralization is an indicator from 1 to 5 and shows the level at which the bargaining is conducted. 1 means very low centralization at the company level and 5 on a national level. The minimum wage indicator ranges from 1 (no minimum wage) to 8 (national minimum wage set by the government). The union density indicator consists of the percentage of wage and salary earners which are organized in a union. The union coverage indicator shows the percentage of employees whose wage bargaining is affected by wage bargaining agreements.

The employment protection legislation indicator ranges from 0 to 6 . The higher the value the higher the degree of protection. The indicator is taken from the OECD labour statistics database.

According to NiCKELL (2006), I construct the replacement rates for the first year, the second and third year, as well as for the fourth and fifth year of unemployment as indicators for the unemployment benefit system. Additionally, I include an overall indicator for the level of benefits which is the unweighted average of the three sub-measures, and a 
measure for the benefit duration. The benefit duration indicator $b d$ equals

$$
b d=0.6 \frac{b r r 23}{b r r 1}+0.4 \frac{b r r 45}{b r r 1}
$$

where brr23 are the second and third year benefits, brr45 the fourth and fifth year benefits, and brr1 the first year benefits. Since the OECD provides such detailed series only until 2003, I had to update the series with help of the OECD tax benefit models available on the OECD homepage. Hence, I use the definitions given by the OECD (see OECD 1994, Chapter 8) to update the series. Note that the tax benefit models provide data on unemployment benefits which are biased for some countries. The particular time series have to be checked and adjusted according to the country-specific definitions available at the OECD homepage (the current link which leads to the country-specific files on benefits and wages is http://www.oecd.org/document/29/0,3343,en_2649_34637_39618653_1_1_1_1,00.html ). The Fondazione Rodolfo de Benedetti delivers data on unemployment benefit coverage for the complete period as a fraction of job seekers entitled to benefits over the total number of job seekers. Some observations are missing for Belgium (2000-2005), Italy (1982-1989 and 2003-2005), Sweden (1982-1994), Switzerland (1982-1984) and the United Kingdom (1996). In order to include it in the model averaging approach, I assign the missing observations the same value as the first preceding or successive observation with a valid value. If both a preceding and successive value is available, I construct the mean.

Data on product market regulation come from the OECD, as well. I use the regulation indicators in energy, transport and communication sectors (ETCR). This database delivers information on the barriers to entry and on public ownership for the described sectors. I use the aggregate indicators in the empirical section. Note that the aggregate ETCR indicator consists of the barriers to entry, the public ownership, and some additional indicators. These additional indicators are not comprehensively available over sectors which is why I cannot take them into account. For a detailed description about the construction of the product market regulation data see CONWAY AND NiCOLETTI (2006).

\subsubsection{Shock Variables and Macroeconomic Controls}

Generally, I closely follow the approach proposed by Nickell ET AL (2005). Note that all data which are required for the construction of the shock variables are provided by the OECD. I construct four shock variables which probably influence the unemployment rate in the short run. The real import price is the import price deflator divided by the GDP deflator. According to the following equation, the shock is the log change of the 
real import price $(I P S)$ times the import share in GDP.

$$
I P S=\frac{\text { Imports }}{G D P} \log \left(\frac{I P_{\text {deflator }}}{G D P_{\text {deflator }}}\right)
$$

with $I P_{\text {deflator }}$ being the import price deflator.

The real interest rate is the long-term interest rate corrected for the current inflation rate.

For the construction of the total factor productivity (TFP) shocks I follow BASSANINI AND DUVAL (2006) and calculate first the change in the log of TFP as

$$
\Delta \ln (T F P)=\frac{\Delta \ln (Y)-\alpha \Delta \ln (T E)+(1-\alpha) \Delta \ln (K)}{\alpha}
$$

with $Y$ equal to the GDP in the business sector, $T E$ is total employment, $K$ the gross capital stock, and $\alpha$ the share of labor income in total business sector income. By cumulating the changes in the log TFP's over years I get the TFP in each year. Finally, I take the deviations from the TFP trend to construct an index for TFP shocks by applying the Hodrick-Prescott filter with a $\lambda$ of 100 .

The labor demand shock is the change in the residuals of a labor demand model to be estimated. Hence, I estimate the following equation for each country and take $\varepsilon$ as the country-specific labor demand shock.

$$
\ln \left(T E_{t}\right)=\beta_{0}+\beta_{1} \ln \left(T E_{t-1}\right)+\beta_{2} \ln \left(T E_{t-2}\right)+\beta_{3} \ln \left(T E_{t-3}\right)+\beta_{4} \ln \left(Y_{t}\right)+\beta_{5} \ln \left(L C_{t}\right)+\varepsilon_{t} .
$$

Again, $T E$ is total employment, $Y$ is the real GDP and $L C$ are the real labor costs per employee. The real labor costs are calculated as the total labor costs of the total economy divided by the number of dependently employed workers.

Data on the change in the inflation rate is taken from the OECD database. Following BACCARO AND REI (2007) I construct this variable as $C P I_{t}-C P I_{t-1}$.

The lagged labor productivity growth (LPG) is the series provided by the OECD. For Austria, information is only available from 1996 on. I use the Total Economy Database information on labor productivity (GDP per hour worked) and extend, using the OECD approach, the labor productivity growth series for Austria as $\left(\ln \left(L P G_{t}-\ln \left(L P G_{t-1}\right) * 100\right.\right.$. Data on public spending on active labor market policy is provided by the OECD.

For the credit constraints I use data from Beck And Demirg-Kunt (2009). More specifically, the indicator for private credit by deposit money banks and other financial institutions over GDP is used. 
The output gap series are delivered by the OECD.

\section{$7 \quad$ References}

Acemoglu, D. And Shimer, R. (1999): Efficient Unemployment Insurance, Journal of Political Economy, Vol. 107(5), 893-928.

Acemoglu, D. And Shimer, R. (2000): Productivity gains from unemployment insurance, European Economic Review, Vol. 44(7), 1195-1224.

Addison, J., Blackburn, M. and Cotti, C. (2009): Do minimum wages raise employment? Evidence from the U.S. retail-trade sector, Labour Economics, Vol. 16(4), 397-408.

Aidt, T. And Tzannatos, Z. (2008): Trade unions, collective bargaining and macroeconomic performance: a review, Industrial Relations Journal, Vol. 39(4), 258-295.

Amable, B., Demmou, L. And Gatti, D. (2007): Employment Performance and Institutions: New Answers to an Old Question, IZA Discussion Papers, No. 2731.

Arulampalam, W. (2001): Is Unemployment Really Scarring? Effects Of Unemployment Experiences On Wages, Economic Journal, Vol. 111(475), 585-606.

BACCARO, L. AND REI, D. (2007): Institutional determinants of unemployment in OECD countries: Does the deregulatory view hold water?, International Organization, Vol. 61(3), 527-569.

Baker, D., Glyn, A., Howell, D. And Schmitt, J. (2005): Labor Market Institutions and Unemployment: A Critical Assessment of the Cross-Country Evidence, chapter 3 of D. Howell, ed., Fighting Unemployment: The Limits of Free Market Orthodoxy, (Oxford University Press).

Baltagi, B. (2003): Economic Analysis of Panel Data, Third Edition, Wiley, England.

Bassanini, A. And Duval, R. (2006): The determinants of unemployment across OECD countries: Reassessing the role of policies and institutions, OECD Economic Department Working Papers, No. 486.

Beck, T. And Demirg-Kunt, A. (2009): Financial Institutions and Markets Across Countries and over Time: The Updated Financial Development and Structure Database. World Bank Economic Review, Vol. 24(1), 77-92.

Belot, M. AND van Ours, J. C. (2004): Does the recent success of some OECD countries in lowering their unemployment rate lie in the clever design of their labor market reforms?, Oxford Economic Papers 56(1), 621-642.

Bennmarker, Mellander, E. And ÖCKert, B. (2009): Do regional payroll tax reductions boost employment?, Labour Economics, Vol. 16(5), 480-489. 
Bertrand, M. And Kramarz, F. (2002): Does Entry Regulation Hinder Job Creation? Evidence from the French Retail Industry, Quarterly Journal of Economics, Vol 117(4), 1369-1413.

Blanchard, O. And Giavazzi, F. (2003): Macroeconomic effects of regulation and deregulation in goods and labor markets, Quarterly Journal of Economics, Vol. 118(3), 879-907.

Blanchard, O. and Wolfers, J. (2000): The Role of Shocks and Institutions in the Rise of European Unemployment: The Aggregate Evidence, Economic Journal, Vol. 110(462), $1-33$.

Calmfors, L. (1993): Centralisation of Wage Bargaining and Macroeconomic Performance, OECD Economics Department Working Papers, No 131.

Calmfors, L. And Driffill, J. (1988): Centralization of wage bargaining, Economic Policy, Vol. 3(1), 13-61.

Conway, P. And Nicoletti, G. (2006): Product Market Regulation in the Non-manufacturing Sectors of OECD Countries: Measurement and Highlights, OECD Economics Department Working Papers, No. 530.

DAVERI, F. AND TABellini, G. (2000): Unemployment, growth and taxation in industrial countries, Economic Policy, Vol. 15(30).

Dority, B. AND Fuess JR., S. (2007): Labor Market Institutions and Unemployment: Can Earlier Findings be Replicated?, Quarterly Journal of Business and Economics, Vol. 46(4), $23-44$.

Dromel, N., Kolakez, E. And Lehmann, E. (2010): Credit Constraints and the Persistence of Unemployment, Labour Economics, forthcoming 2010.

Elmeskov, J., Martin, J. P. and Scarpetta, S. (1998): Key lessons for labour market reforms: evidence from OECD countries' experiences, Swedish Economic Policy Review, Vol. 5(2), 205-252.

Fiori, G., Nicoletti, G., Scarpetta, S. and Schiantarelli, F. (2007): Employment Outcomes and the Interaction Between Product and Labor Market Deregulation: Are They Substitutes or Complements?, IZA Discussion Papers, No. 2770.

Griffith, R., Harrison, R. and Macartney, G. (2007): Product market reforms, labour market institutions and unemployment, Economic Journal, Vol. 117(518), C124-C166.

Holmlund, B. (1998): Unemployment Insurance in Theory and Practice, Scandinavian Journal of Economics, Vol. 100(1), 113-141.

Howell, D. R., BAKer, D., Glyn, A. And Schmitt, J. (2007): Are protective labor market institutions at the root of unemployment? A critical Review of the Evidence, Capitalism and Society, Vol 2(1), 1-71.

IMF (2003): World Economic Outlook Chapter IV, April 2003. 
Lalive, R. (2007): Unemployment Benefits, Unemployment Duration, and Post-Unemployment Jobs: A Regression Discontinuity Approach, AEA Papers and Proceedings, Vol. 97(2), 108-112.

LJungqvist, L. (2002): How Do Lay-Off Costs Affect Unemployment?, Economic Journal, Vol. 112(482), 829-853.

Magnus, J., Powell, O. And Prüfer, P. (2010): A comparison of two model averaging techniques with an application to growth empirics, Journal of Econometrics, Vol. 154(2), 139-153.

Manning, A. (1995): How do we know that real wages are too high?, Quarterly Journal of Economics, Vol. 110(4), 1111-1125.

Melitz, M. (2003): The Impact of Trade on Intra-Industry Reallocations and Aggregate Industry Productivity, Econometrica, Vol. 71(6), 1695-1725.

Nickell, S. (1997): Unemployment and Labor Market Rigidities: Europe versus North America, Journal of Economic Perspectives, Vol. 11(3), 55-74.

Nickell, W. (2006): The CEP-OECD Institutions Data Set (1960-2004), CEP Discussion Paper No. 759. With data set: http://cep.lse.ac.uk/pubs/download/data0759.zip.

Nickell, S. And Nunziata, L. (2001): Labour Market Institutions Database, CEP Discussion Paper No. 502.

Nickell, S., Nunziata, L. And Ochel, W. (2005): Unemployment in the OECD since the 1960s. What do we know?, Economic Journal, Vol. 115(500), 1-27.

Nicoletti, G. and Scarpetta, S. (2005), Product Market Reforms and Employment in OECD Countries, OECD Economics Department Working Papers, No. 472.

OECD (1994): The OECD Job Study: Evidence and Explanations, Part II - The Adjustment Potential of the Labour Market, Paris: OECD.

OECD (2006): Reassessing the Role of Policies and Institutions for Labour Market Performance: A Quantitative Analysis, OECD Employment Outlook Chapter 7.

Oswald, A. (1997): The missing piece of the unemployment puzzle, Inaugural Lecture, University of Warwick, November.

Planas, C., Roeger, W. And Rossi, A. (2007): How much has labour taxation contributed to European structural unemployment?, Journal of Economic Dynamics and Control, Vol. 31(4), 1359-1375.

Røed, K. And Zhang, T. (2003): Does Unemployment Compensation Affect Unemployment Duration?, Economic Journal, Vol 113(484), 190-206.

Sala-I-Martin, X., Doppelhofer, G. And Miller, R. (2004): Determinants of LongTerm Growth: A Bayesian Averaging of Classical Estimates (BACE) Approach, American Economic Review, Vol. 94(4), 813-835. 
Scarpetta, S. (1996): Assessing the Role of Labour Market Policies and Institutional Settings of Unemployment: A Cross-Country Study, OECD Economic Studies, No. 26, 1996/1.

Schiantarelli, F. (2008): Product Market Regulation and Macroeconomic Performance: A Review of Cross Country Evidence, Boston College Working Papers in Economics, No. 623.

Stigler, G. (1946): The economics of minimum wage legislations, American Economic Review, Vol. 36(3), 358-65.

Stock, J. And Staiger, D. (1997): Instrumental Variables Regression with Weak Instruments, Econometrica, Vol. 65(3), 557-586.

Tatsiramos, K. (2009): Unemployment Insurance in Europe: Unemployment Duration and subsequent Employment Stability, Journal of the European Economic Association, Vol. $7(6), 12251260$.

VAN OuRs, J. AND Vodopivec, M. (2008): Does reducing unemployment insurance generosity reduce job match quality?, Journal of Public Economics, Vol. 92(3-4), 684-695.

Visser, J. (2009): The ICTWSS Database: Database on Institutional Characteristics of Trade Unions, Wage Setting, State Intervention and Social Pacts in 34 countries between 1960 and 2007. 